\title{
Investigation of strength characteristics of natural stones in Ürgüp (Nevşehir/Turkey)
}

\author{
Eren PAMUK a,* , Aydın BÜYÜKSARAÇ b \\ a Department of Geophysical Research General Directorate of the Mineral Research \& Exploration of Turkey, 06800 Ankara Turkey \\ b Bitlis Eren University, Department of Civil Engineering, TR-13000, Bitlis Turkey
}

\section{ART I C LE INFO}

\section{Article history:}

Received 11 April 2017

Received in revised form 25 July 2017

Accepted 09 August 2017

\section{Keywords:}

Non-destructive tests

Natural Stones

Ürgüp (Nevşehir)

\begin{abstract}
Natural Stones of Ürgüp (Nevşehir) are commonly used both indoor and outdoor due to their easily given form at the stone quarry. That's why some geotechnical and geomechanical tests must be done in order to determine quality separation and strength characterisation. Destructive and non-destructive tests were done on the five different colored and featured samples $\left(10 \times 10 \times 10 \mathrm{~cm}^{3}\right)$ named Vişne, Devetüyü, Gülkurusu, Kirli Beyaz and Sarı obtained from the study area. The uniaxial stress test was made in the frame of destructive tests. Schmidt hammer and ultrasound tests were applied in the frame of nondestructive tests. Results of destructive and non-destructive tests were compared and weaknesses and advantages of all methods were discussed. One of the samples named Sar has more strength according to other samples. Gülkurusu and Kirli Beyaz samples have the lowest strength. Similarly, Schmidt hammer and ultrasound measurements gave high strength results. Because of destructive and nondestructive testing methods from different natural stone samples with non-uniform mineral combination were in accordance. Non-destructive testing methods can be used for strength characterisation of natural stones. In this case, geomechanical features and quality ranks can be determined with in-situ tests without carrying the samples to laboratories.
\end{abstract}

(c) 2017. Turkish Journal Park Academic. All rights reserved. Schmidt hammer rebound numbers with impact strength index. Karakuş and Tütmez (2006) used Uniaxial Compressive Strength, Point Load Index test, Schmidt Hammer Hardness test, ultrasonic velocity (Vp) for nine different rocks. Sharma and Singh (2008) adjusted the mechanical properties of three metamorphic and sedimentary rocks, one igneous and associated to P-wave velocity. Kurtuluş et al. (2010) analyzed the mechanical and physical features of the andesite in Gökçeada Island. Işılk et al. (2015) and Dinçer et al. (2012) investigated Ahlat natural stones (ignimbrites) for the industrial usage of them.

There are many studies in Nevsehir and its surroundings about tuff stones. For example Erdoğan (1986) studied the physical properties of tuff stones in Nevşehir-Ürgüp region. Topal and Doyuran (1997) examined both mass and material properties of the tuff stones. Aydan and Ulusay (2003) analyzed mechanical and physical characteristics of the Cappadocia tuff stones. Yaşar and Erdoğan (2008) determined the physicomechanical properties of Nevşehir

\footnotetext{
* Corresponding author.

Tel.: +0 5323849562

E-mail address: erenpamuk@mta.gov.tr
} 
pumice. Yaşar et al. (2009) studied mechanical and physical properties of tuff stones in designated locations in Kayseri and Nevşehir in terms of usage of the tuff stones in industry.

For the aim of this study, various natural stones from Ürgüp (Nevșehir), which have been used commonly both indoor and outdoor due to their easily given form at the stone quarry in Turkey, were collected. Ultrasonic pulse velocity (UPV) and the Schmidt rebound hammer (SRH) tests are utilized on the specimens. After, these specimens are used for UCS (Uniaxial Compressive Strength) testing. In laboratory studies, P-wave velocity and Rebound Index (RI) are measured. Then UCS tests on the specimens are performed using a standard stiff compression-testing machine. Another purpose of this study is to create a statistical relationship between Schmidt hammer rebound numbers and UCS and P-wave velocity and UCS. There is a linear relationship among P-wave velocity, rebound numbers and UCS in this study.

\section{Methodology}

\subsection{Schmidt Hammer test}

The Schmidt Rebound Hammer (SRH), which is cheap, fast and useful non-destructive method, is used in order to evaluate rock quality materials. SRH gives information of surface rebound hardness which is associated with compressive strength (Shariati et al. 2011). The hammer is pressed onto the rock surface. The hammer has a springloaded mass which is released versus a plunger. The plunger effects the rock surface and the mass repulsions, the rebound value of the mass is measured (Sharma et al. 2011) (Figure 1).

\subsection{Ultrasonic Pulse Velocity Method}

In the ultrasonic pulse velocity (UPV) methods, it is analyzed the propagation variations of ultrasonic velocity wave. This method, which makes an examination of the material homogeneity possible, can be considered as important methods for evaluation structures of concrete or natural stones (Lorenzi et al., 2007).

The UPV equipment consists of a receiver, transducer and an indicator (Figure 2) (Sharma et al. 2011).

The indicator represents the travel time from the transducer to the receiver. Equation (1) shows that determining the pulse velocity;

$$
\mathrm{V}=\mathrm{L} / \mathrm{T}
$$

where V: pulse velocity $(\mathrm{km} / \mathrm{s})$, L: path length $(\mathrm{cm}), \mathrm{T}$ : transit time $(\mu s)$.

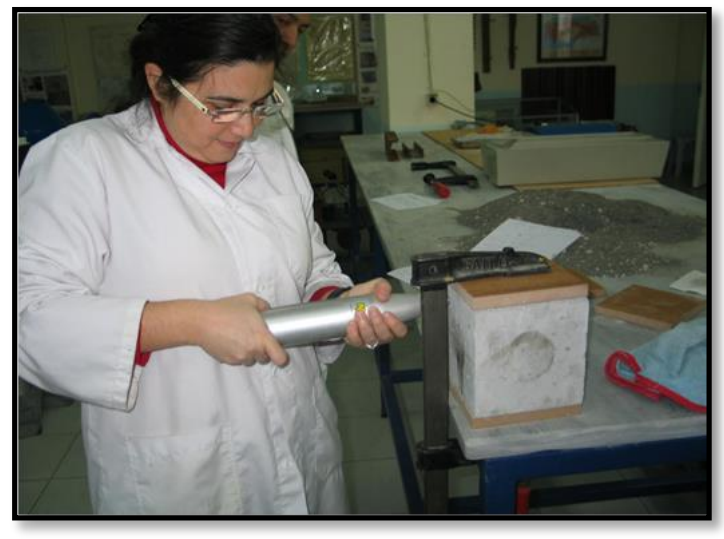

Figure 1. Application of a Schmidt Rebound Hammer (SRH).

Pulse velocity measurements can be performed in three ways depending on the receiver and transmitter positions. These are as follows; I) direct transmission II) semi-direct transmission III) surface (indirect) transmission (Figure 2) (Sharma et al. 2011).

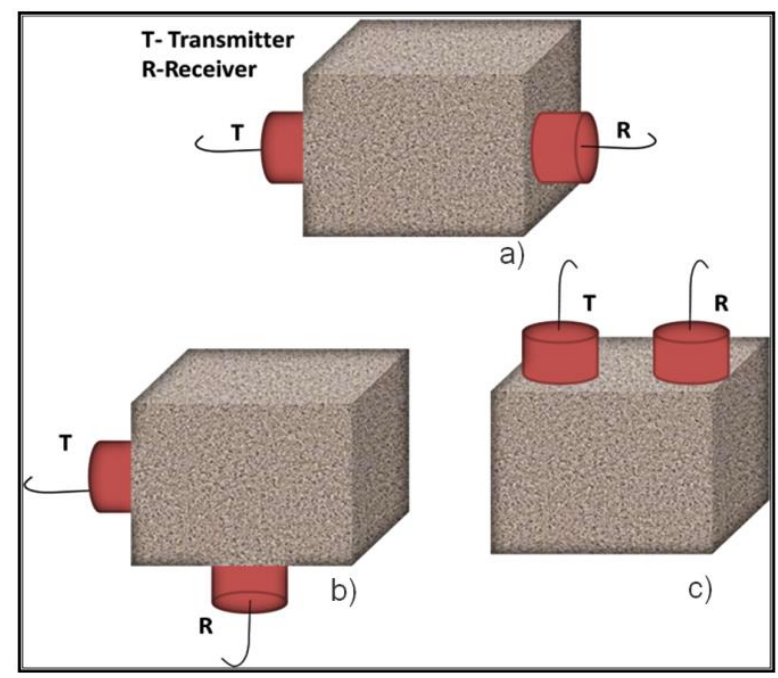

Figure 2. Pulse velocity testing equipment (PUNDIT) and its application to the specimen a) Direct; (b) Semi-direct; c) Indirect (surface) transmission.

\subsection{Uniaxial Compression Test}

Uniaxial compressive strength (UCS) method, which is the destructive test, is one of the most widely used to determine the quality separation and strength of characterization of concrete and natural stones (Figure 3). 


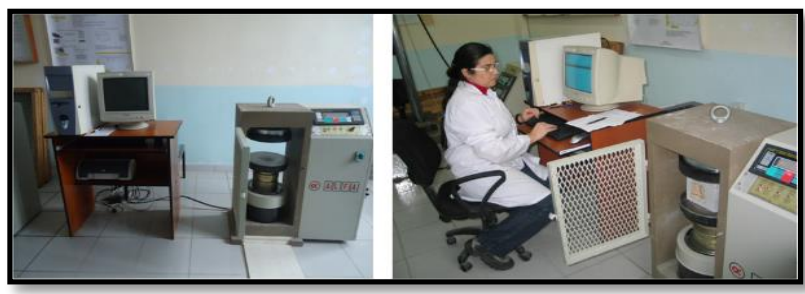

Figure 3. Compressive test equipment

\section{Geological characteristics of the study area}

The study is carried out within the Ürgüp region (Nevşehir/Turkey) (Figure 4). Eruptions of the Erciyes, Hasan and Akdag Mountains volcanoes in the late Miocene to Pliocene covered a big place which is about $11,000 \mathrm{~km}^{2}$ with $400 \mathrm{~m}$ thick pyroclastic ignimbrite (Yaşar et al., 2009). After, dark-toned andesitic and basaltic lavas covered the pyroclastic ignimbrite in the late Pliocene and Early Pleistocene (Yasar et al., 2009). In the study area and its surroundings, deposits of the volcano-sedimentary sequence of the Ürgüp formation are observed as deeply and broadly. The Ürgüp formation includes Neogene sequence composed of ignimbrites, tuff stones, tuffite, volcanic ash, lahar, and marl inclusions (Baba et al., 2005).

\section{Laboratory studies}

UPV and SH tests were utilized on cube specimens before the destructive compressive tests (Figure 5). The UPV measurements were carried out on 15 specimens using the method of direct transmission and probes of $1 \mathrm{MHz}$. The measurements were utilized on cubic samples along the three directions $\mathrm{x}, \mathrm{y}$ and $\mathrm{z}$. A set of three measurements was taken for each direction. The velocity was calculated directly from the instrument using the formula 1 . The average velocity values were calculated on the number of measurements made for each direction.

In Table 1, the velocity values of the $\mathrm{P}$ waves recorded for each specimen in the three directions are reported. It can be seen that a variability of the UPV results depends on the measurement direction. The pulse velocities are determined using a direct method which utilizes among opposite faces for specimens.

When the obtained UPV results are examined; $\mathrm{P}$ wave velocities vary between $3.9 \mathrm{~km} \cdot \mathrm{s}^{-1}$ and $6 \mathrm{~km} \cdot \mathrm{s}^{-1}$. It is seen that the Devetüyü specimen has relatively higher speed values. Kirli beyaz has lower speed values among the samples. The reason why the speed values differ in the different directions in the same samples is due to the fact that the samples are not homogeneous.

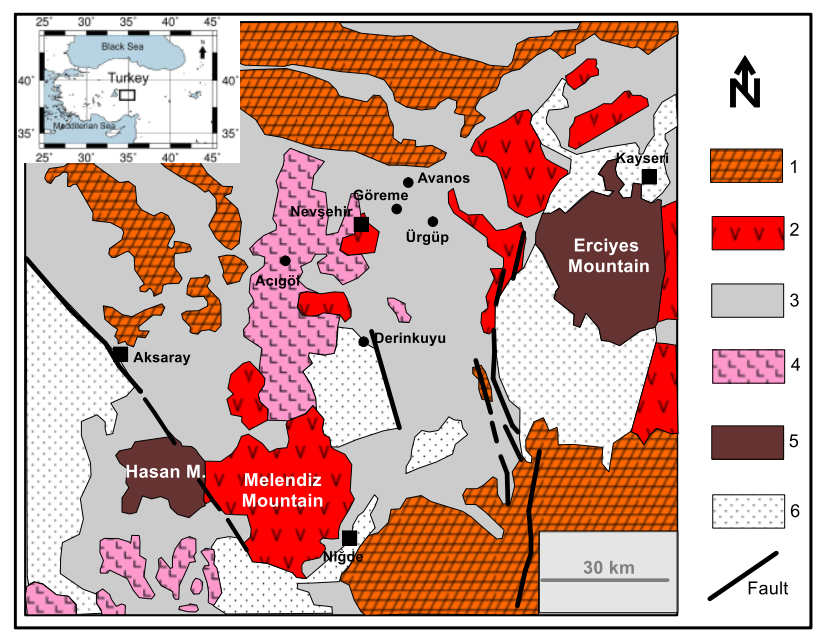

Figure 4. Simplified geological map of the Cappadocia region (modified from Koşaroğlu 2011) (1-Bedrocks, 2-Miocene-Pliocene volcanic Complex, 3-Ignimbrits and co-aged terrestrial sediments, 4- Monogenic Quaternary volcanoes, 5-Wide Quaternary volcanoes, 6-Quaternary alluviums).

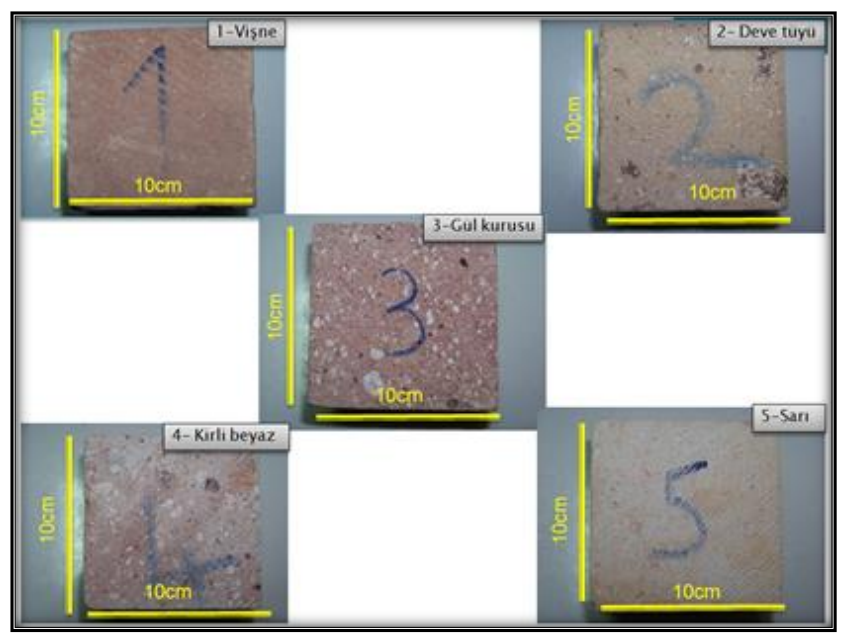

Figure 5. Specimens of natural stones from study area

Table 1. Ultrasonic pulse velocity $(\mathrm{Vp})$ measured on the samples

\begin{tabular}{|c|c|c|c|c|c|c|c|c|c|}
\hline $\begin{array}{c}\text { The Name of } \\
\text { the Samples }\end{array}$ & \multicolumn{3}{|c|}{$\begin{array}{c}\text { Measured Transition } \\
\text { Times (msec) }\end{array}$} & \multicolumn{3}{c|}{$\begin{array}{c}\text { Transceiver width } \\
\text { (cm) }\end{array}$} & \multicolumn{3}{c|}{$\begin{array}{c}\text { P-wave velocity } \\
\left(\mathrm{kmms}^{-1}\right)\end{array}$} \\
\hline 1A & 43 & 41 & 43 & 10 & 10 & 10 & 4.3 & 4.1 & 4.3 \\
\hline 1B & 45 & 40 & 46 & 10 & 10 & 10 & 4.5 & 4 & 4.6 \\
\hline 1C & 46 & 43 & 41 & 10 & 10 & 10 & 4.6 & 4.3 & 4.1 \\
\hline 2A & 51 & 53 & 48 & 10 & 10 & 10 & 5.1 & 5.3 & 4.8 \\
\hline 2B & 60 & 51 & 52 & 10 & 10 & 10 & 6 & 5.1 & 5.2 \\
\hline 2C & 54 & 49 & 57 & 10 & 10 & 10 & 5.4 & 4.9 & 5.7 \\
\hline 3A & 52 & 47 & 46 & 10 & 10 & 10 & 5.2 & 4.7 & 4.6 \\
\hline 3B & 50 & 46 & 52 & 10 & 10 & 10 & 5 & 4.6 & 5.2 \\
\hline 3C & 45 & 49 & 49 & 10 & 10 & 10 & 4.5 & 4.9 & 4.9 \\
\hline 4A & 48 & 48 & 51 & 10 & 10 & 10 & 4.8 & 4.8 & 5.1 \\
\hline 4B & 54 & 48 & 50 & 10 & 10 & 10 & 5.4 & 4.8 & 5 \\
\hline 4C & 48 & 53 & 46 & 10 & 10 & 10 & 4.8 & 5.3 & 4.6 \\
\hline 5A & 50 & 42 & 45 & 10 & 10 & 10 & 5 & 4.2 & 4.5 \\
\hline 5B & 40 & 47 & 39 & 10 & 10 & 10 & 4 & 4.7 & 3.9 \\
\hline 5C & 43 & 41 & 44 & 10 & 10 & 10 & 4.3 & 4.1 & 4.4 \\
\hline
\end{tabular}


The Schmidt hammer test was performed on 15 specimens with a digital hammer which is type DIGI_SCHMIDT with impact energy of $2.207 \mathrm{Nm}$. A mesh of ten points was marked on each cube sample. The mean value of the ten rebound readings was calculated for each specimen and the average rebound index was determined for each cube sample.

Table 2. Schmidt hammer test results.

\begin{tabular}{|c|c|c|c|c|c|c|c|c|c|c|c|}
\hline \multirow{2}{*}{$\begin{array}{c}\text { Specimen } \\
\text { number }\end{array}$} & \multicolumn{10}{|c|}{ Rebound Index } & \multirow{2}{*}{ Average (R) } \\
\cline { 2 - 10 } & $\mathbf{1}$ & $\mathbf{2}$ & $\mathbf{3}$ & $\mathbf{4}$ & $\mathbf{5}$ & $\mathbf{6}$ & $\mathbf{7}$ & $\mathbf{8}$ & $\mathbf{9}$ & $\mathbf{1 0}$ & \\
\hline 1A & 23 & 20 & 23 & 19 & 21 & 24 & 18 & 22 & 18 & 22 & 21 \\
\hline 1B & 23 & 21 & 18 & 25 & 22 & 22 & 18 & 25 & 24 & 22 & 22 \\
\hline 1C & 23 & 21 & 21 & 23 & 22 & 22 & 18 & 18 & 19 & 20 & 20.7 \\
\hline 2A & 19 & 19 & 16 & 26 & 19 & 23 & 19 & 21 & 17 & 23 & 20.2 \\
\hline 2B & 17 & 19 & 16 & 18 & 17 & 16 & 17 & 16 & 14 & 19 & 16.9 \\
\hline 2C & 22 & 22 & 25 & 19 & 27 & 21 & 20 & 18 & 23 & 17 & 21.4 \\
\hline 3A & 18 & 17 & 19 & 16 & 16 & 18 & 18 & 19 & 14 & 17 & 17.2 \\
\hline 3B & 20 & 18 & 19 & 21 & 21 & 20 & 17 & 19 & 15 & 17 & 18.7 \\
\hline 3C & 20 & 19 & 21 & 18 & 19 & 20 & 22 & 23 & 17 & 15 & 19.4 \\
\hline 4A & 17 & 19 & 16 & 17 & 14 & 19 & 22 & 19 & 17 & 20 & 18 \\
\hline 4B & 18 & 15 & 14 & 22 & 14 & 21 & 18 & 23 & 19 & 16 & 18 \\
\hline 4C & 18 & 17 & 15 & 15 & 17 & 15 & 16 & 16 & 15 & 14 & 15.8 \\
\hline 5A & 20 & 21 & 21 & 22 & 18 & 21 & 22 & 19 & 19 & 24 & 20.7 \\
\hline 5B & 22 & 23 & 18 & 22 & 22 & 21 & 19 & 25 & 24 & 23 & 21.9 \\
\hline 5C & 25 & 24 & 24 & 20 & 22 & 24 & 22 & 21 & 23 & 25 & 23 \\
\hline
\end{tabular}

The rebound index and average values of each specimen are reported in Table 2 . The rebound number was obtained by taking 10 readings for each specimen.

When the obtained SRH values are examined, the mean $\mathrm{R}$ values range from 15.8 to 23 . Sarl sample has max value; kirli beyaz has a minimum R-value. The uniaxial compressive strength test was realized in accordance with ISRM suggested methods. In this study, we used The Alfa 100 tons universal testing machine.

The average values of UCS of the natural stones are listed in Table 3 and Figure 6. The strength values range from a low of $8 \mathrm{MPa}$ for Deve tuyu to a high of $22 \mathrm{MPa}$ for Sari.

Table 3. Compressive test results

\begin{tabular}{|c|c|c|c|c|c|}
\hline $\begin{array}{c}\text { The Name of } \\
\text { the Samples }\end{array}$ & $\begin{array}{c}\text { Weight } \\
\mathbf{( g )}\end{array}$ & Dimensions (mm) & $\begin{array}{c}\text { Apparent Specific } \\
\text { gravity }\left(\mathbf{g} / \mathbf{c m}^{\mathbf{3}}\right)\end{array}$ & $\begin{array}{c}\text { Breaking } \\
\text { Load (N) }\end{array}$ & $\begin{array}{c}\text { Uniaxial } \\
\text { Compressive } \\
\text { Strength N/mm }\end{array}$ \\
\hline 1A & 1852 & $1000 \times 1000 \times 1000$ & 1.85 & 164400 & 16.440 \\
\hline 1B & 1870 & $1000 \times 1000 \times 1000$ & 1.87 & 140580 & 14.058 \\
\hline 1C & 1813 & $1000 \times 1000 \times 1000$ & 1.81 & 168140 & 16.814 \\
\hline 2A & 1700 & $1000 \times 1000 \times 1000$ & 1.7 & 134680 & 13.468 \\
\hline 2B & 1598 & $1000 \times 1000 \times 1000$ & 1.6 & 82120 & 8.212 \\
\hline 2C & 1750 & $1000 \times 1000 \times 1000$ & 1.75 & 115580 & 11.558 \\
\hline 3A & 1811 & $1000 \times 1000 \times 1000$ & 1.81 & 103520 & 10.352 \\
\hline 3B & 1804 & $1000 \times 1000 \times 1000$ & 1.8 & 105680 & 10.568 \\
\hline 3C & 1847 & $1000 \times 1000 \times 1000$ & 1.85 & 90320 & 9.032 \\
\hline 4A & 1797 & $1000 \times 1000 \times 1000$ & 1.8 & 111860 & 11.186 \\
\hline 4B & 1806 & $1000 \times 1000 \times 1000$ & 1.81 & 95200 & 9.520 \\
\hline 4C & 1773 & $1000 \times 1000 \times 1000$ & 1.77 & 133680 & 13.368 \\
\hline 5A & 1880 & $1000 \times 1000 \times 1000$ & 1.88 & 63600 & 6.360 \\
\hline 5B & 1878 & $1000 \times 1000 \times 1000$ & 1.88 & 172300 & 17.230 \\
\hline 5C & 1931 & $1000 \times 1000 \times 1000$ & 1.93 & 225300 & 22.530 \\
\hline & & & & & \\
\hline
\end{tabular}
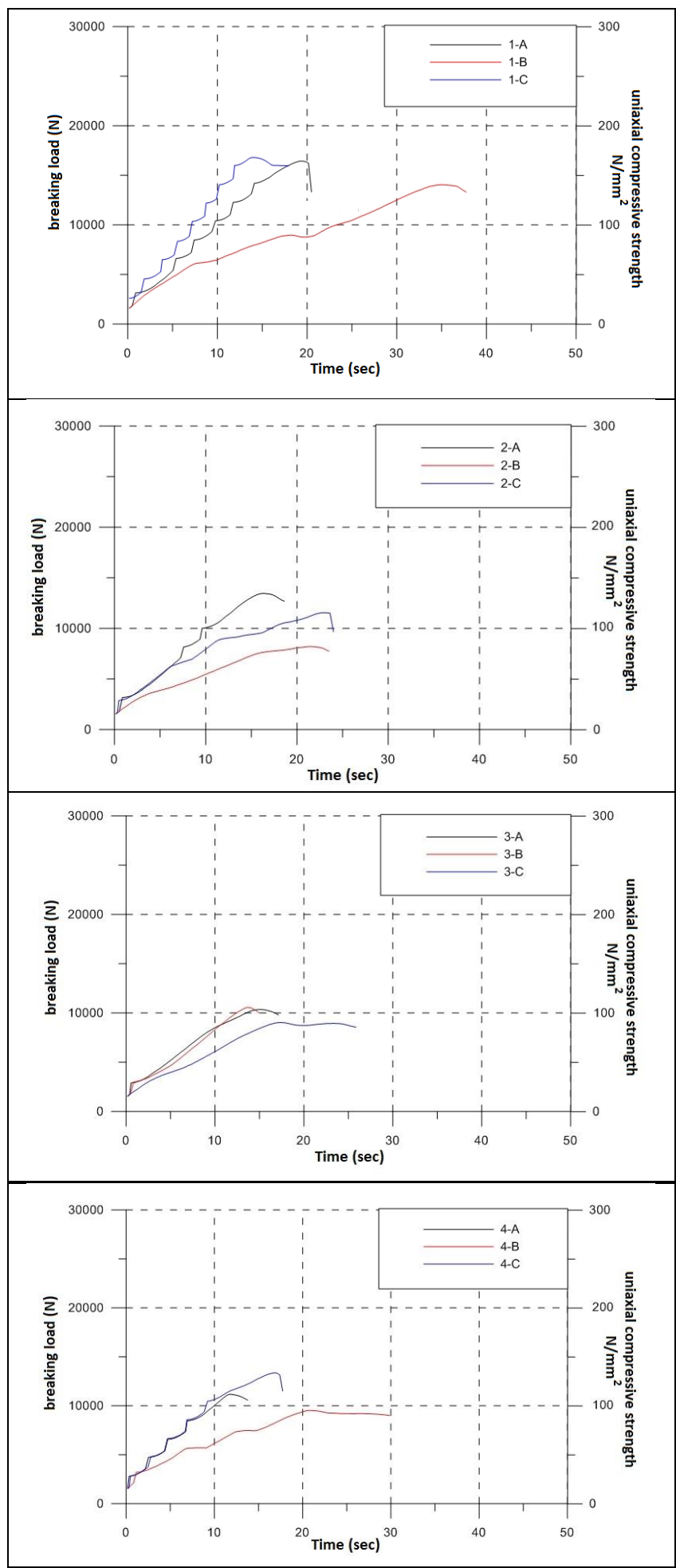


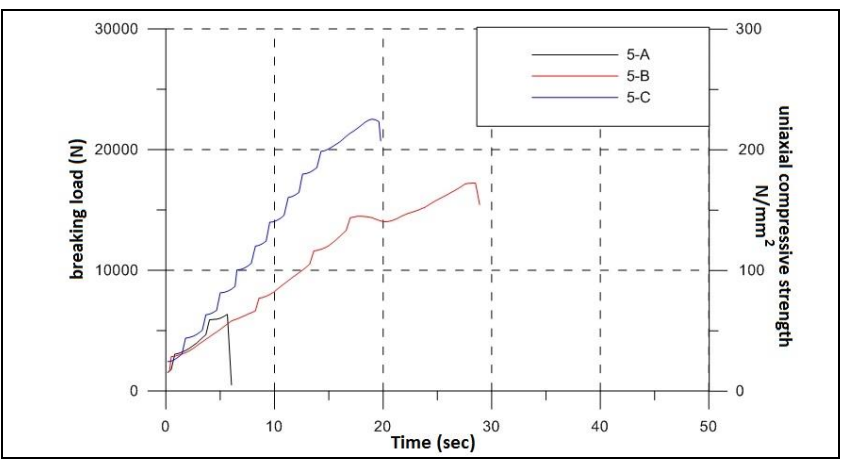

Figure 6. Compressive strength of Specimens (1-Vişne, 2-Deve tüyü, 3-Gül kurusu, 4-Kirli beyaz, 5-Sarı)

\section{Statistical Analysis}

Regression analyses were carried out among UCS and UPV, SHT. The linear regression represented the best-fitted relation in this study. The graphic of the P-wave velocity as a function of UCS shows in Figure 7. There is a linear relationship between UCS and $\mathrm{Vp}$ in this study. A correlation was determined between UCS and Vp (Eq. 2).

$$
\mathrm{UCS}=17.47 \mathrm{Vp}-23.93
$$

where UCS and Vp are Uniaxial Compressive Strength and Pwave velocity, respectively.

In the same way, a linear relationship was realized between Rebound Index and UCS with a correlation coefficient of 0.73 (Figure 8). The equation of this relation is:

$$
\mathrm{UCS}=1.77 \mathrm{SH}-22.04
$$

where UCS and SH are Uniaxial Compressive Strength and Schmidt hammer Rebound Index, respectively.

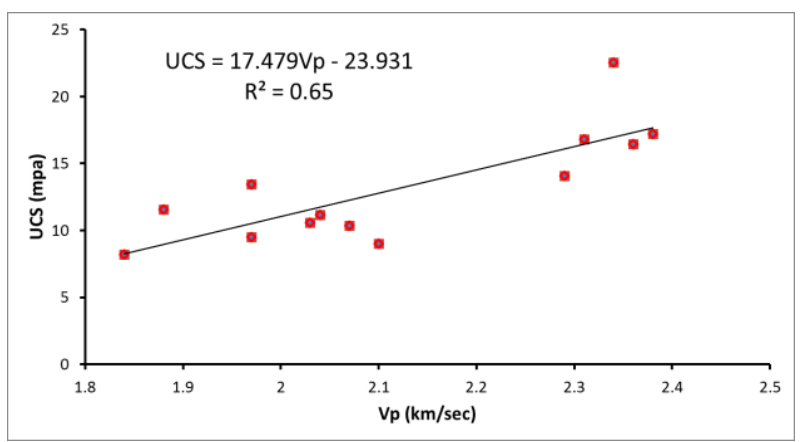

Figure 7. P-wave velocity versus UCS

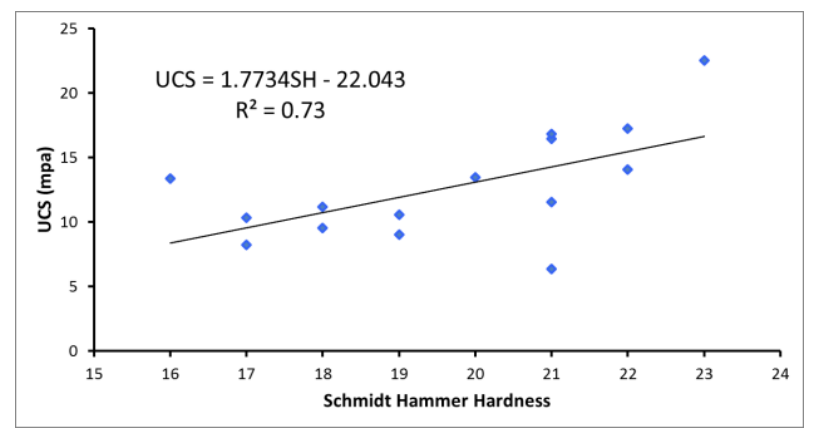

Figure 8. Rebound Index versus UCS

In this study, the empirical methods were utilized by comparison their results with each other. Data from all test were used in the empirical equation to determine the other strength properties of the natural stones. The calculated values of UCS were given with the measured values of UCS in Table 4.

Table 4. Comparison with Average UCS from the Compressive test

\begin{tabular}{|c|c|c|c|c|c|}
\hline \multirow{2}{*}{$\begin{array}{c}\text { Samples } \\
\text { group }\end{array}$} & \multirow{2}{*}{$\begin{array}{c}\text { Average UCS } \\
\text { (N/mm²-MPa) of } \\
\text { Compressive test }\end{array}$} & \multirow{2}{*}{$\begin{array}{c}\text { Average UCS from } \\
\text { Statistical Approach } \\
\text { using Vp Values } \\
\left(\mathbf{N} / \mathbf{m m}^{2}-\mathrm{MPa}\right)\end{array}$} & \multirow{2}{*}{ 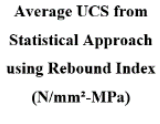 } & \multicolumn{2}{|c|}{ Percent Difference \% } \\
\hline & & & & $v_{p}$ Values & $\begin{array}{c}\text { Rebound } \\
\text { Index }\end{array}$ \\
\hline 1 & 15.77 & 16.62 & 15.76 & 5.39 & 0.07 \\
\hline 2 & 11.08 & 9.22 & 12.22 & 16.77 & 10.30 \\
\hline 3 & 9.98 & 12.32 & 10.45 & 22.12 & 4.67 \\
\hline 4 & 11.36 & 12.19 & 8.68 & 0.35 & 23.58 \\
\hline 5 & 15.37 & 16.33 & 16.94 & 6.22 & 19.19 \\
\hline
\end{tabular}
and Average UCS from Statistical Approach using Eq. 2-3.

\section{Conclusions}

Some characteristics of tuff stones such as uniaxial compressive strength (UCS), hardness (SH) were investigated using the ultrasonic pulse velocity (UPV) test, which is a Non-Destructive Testing (NDT) method. The results are correlated with the results of Schmidt Rebound Hammer (SRH) and uniaxial compressive strength (UCS) tests. Some properties were correlated using simple regression analysis. The results have been obtained that there were found well correlated between all parameters.

According to results, the specimen Sar1 has the maximum strength $(\sim 20000 \mathrm{~N})$. Vişne has second big strength values after the Sari $(\sim 15000 \mathrm{~N})$. Devetüyü and Kirlibeyaz have same strength values nearly $12000 \mathrm{~N}$. The lowest values were obtained for Gülkurusu (10000 N).

Values of velocities and hardness belong to samples presented similarities. However, the samples are ignimbrites rocks and have heterogeneity. That's why there were some incompatibilities. Although there was dispersion between physical and mechanic treatments, non-destructive and destructive methods could be correlated. The relation coefficient is 0.65 for UCS and Vp and 0.73 for UCS and hardness. It means non-destructive method can be used instead of destructive methods. It will be supplied time and financial advantage. 


\section{Acknowledgements}

We would like to thank Kaptaş A.Ş for providing the rock samples. In addition, we would like to thank reviewers for constructive support and helpful comments.

\section{References}

Aydan, Ö., and Ulusay, R. 2003. Geotechnical and geoenvironmental characteristics of man-made underground structures in Cappadocia, Turkey. Engineering Geology, 69(3), 245-272.

Baba, A., Kaya A. and Türk N. 2005. Fairy Chimneys of Cappadocia and their engineering properties. Journal of Applied Sciences, ISSN 1812-5654, 5 (5): 800-805.

Dinçer, İ., Özvan, A., Akın, M., Tapan, M. and Oyan V. 2012. İgnimbiritlerin kapiler su emme potansiyellerinin değerlendirilmesi: Ahlat Taşı örneği, Yüzüncü Yll Üniversitesi Fen Bilimleri Enstitüsü Dergisi, 17, 64-71.

Erdoğan, M. 1986. Nevşehir-Ürgüp Yöresi Tüflerinin Malzeme Jeolojisi Açısından Araştırılması. Unpublished Phd Thesis. Istanbul Technical University. Faculty of Mines.

Fort, R., de Buergo, M. A., and Perez-Monserrat, E. M. 2013. Nondestructive testing for the assessment of granite decay in heritage structures compared to quarry stone. International Journal of Rock Mechanics and Mining Sciences, 61, 296-305.

Işık, E., Bakıș, A., Akıllı, A., and Hattaoğlu, F. 2015. Usability of Ahlat Stone as Aggregate in Reactive Powder Concrete, Int. Journal of Applied Sciences and Engineering Research, 4(4), 507-514.

Karakuş, M., and Tütmez, B. 2006. Fuzzy and multiple regression modelling for evaluation of intact rock strength based on point load, Schmidt hammer and sonic velocity. Rock mechanics and rock engineering, 39(1), 45-57.

Kurtuluş, C., Irmak, T. S., and Sertçelik, I. 2010. Physical and mechanical properties of Gokceada: Imbros (NE Aegean Sea) island andesites. Bulletin of engineering geology and the environment, 69(2), 321-324.

Koşaroğlu, S. 2011. Kapadokya Bölgesi Sı̆̆ Yapısının Gravite Yöntemiyle Modellenmesi. Master Thesis, Cumhuriyet University.

Lorenzi, A., Tisbierek, F. T., and Silva, L. C. P. 2007. Ultrasonic pulse velocity análysis in concrete specimens. In IV Conferencia Panamericana de END, Buenos Aires.

Shariati, M., Ramli-Sulong, N. H., Arabnejad, M. M. KH., Shafigh, P., and Sinaei, H. 2011. Assessing the strength of reinforced concrete structures through Ultrasonic Pulse Velocity and Schmidt Rebound Hammer tests. Scientific Research and Essays, 6(1), 213-220.

Sharma, P. K., and Singh, T. N. 2008. A correlation between P-wave velocity, impact strength index, slake durability index and uniaxial compressive strength. Bulletin of Engineering Geology and the Environment, 67(1), 17-22.

Sharma, P. K., Khandelwal, M., and Singh, T. N. 2011. A correlation between Schmidt hammer rebound numbers with impact strength index, slake durability index and P-wave velocity. International Journal of Earth Sciences, 100(1), 189-195.

Topal, T., and Doyuran, V. 1997. Engineering geological properties and durability assessment of the Cappadocian tuff. Engineering Geology, 47(1-2), 175-187.
Vasconcelos, G., Lourenço, P. B., Alves, C. A., and Pamplona, J. 2007. Prediction of the mechanical properties of granites by ultrasonic pulse velocity and Schmidt hammer hardness. North American Masonry Conference June 3-7 Missouri USA,

Yaşar, E., and Erdogan, Y. 2008. Strength and thermal conductivity in lightweight building materials, bull. Eng. Geol. Environ, 67, 513519.

Yaşar, E., Tolgay, A., and Teymen, A. 2009. Industrial usage of Nevsehir-Kayseri (Turkey) tuff stone. World Appl Sci J, 7(3), 271284. 